\title{
Salt Stress Induces Shoot Formation and Physiological and Biochemical Changes in Miscanthus sacchariflorus
}

\author{
Chuntao Hong ${ }^{1}$, Bingsong Zheng ${ }^{2}$, Haipeng Guo ${ }^{3^{*}}$ and Jianhong Zhang ${ }^{1^{*}}$
}

\author{
${ }^{1}$ Academy of Agricultural Sciences, Ningbo City, China \\ ${ }^{2}$ School of Forestry \& Biotechnology, Zhejiang A \& F University, China \\ ${ }^{3}$ School of Marine Sciences, Ningbo University, China
}

\begin{abstract}
Miscanthus (M.) sacchariflorus is an important perennial bioenergy feedstock. To investigate its responses to salt stress, $M$. sacchariflorus seedlings were grown hydroponically for $14 \mathrm{~d}$ with the different concentrations of $\mathrm{NaCl}(0,50,100$ and $200 \mathrm{mM})$. Our results showed that $\mathrm{NaCl}$ treatment significantly inhibited plant growth and net photosynthetic rate of $M$. sacchariflorus. The limiting factor of photosynthesis was changed from stomatal factor to non-stomatal factor with the increase in $\mathrm{NaCl}$ concentration. The declined degree in chlorophyll fluorescence parameters was less than that in net photosynthetic rate. Salt stress dramatically triggered new shoot formation and enhanced contents of proline and MDA, activities of SOD, POD and CAT in leaves, roots and shoots. In addition, the activities of SOD and POD in shoot were always higher than that in leaf and root in all salt concentrations and the new shoot formation was positive correlation with the antioxidant enzymes activity under less than $100 \mathrm{mM} \mathrm{NaCl}$ stress. Therefore, higher activities of SOD and POD, which could protect new shoots from lipid peroxidation, could be an important mechanism for new shoots to resist higher salt stress.

Keywords

Miscanthus sacchariflorus, Salt stress, New shoot, Photosynthesis, Antioxidant enzymes

\section{Abbreviations}

$\mathrm{P}_{\mathrm{N}}$ : Net Photosynthetic Rate; $\mathrm{g}_{\mathrm{s}}$ : Stomatal Conductance; $\mathrm{C}_{\mathrm{i}}$ : Intercellular $\mathrm{CO}_{2}$ Concentration; E: Transpiration Rate; $\mathrm{F}_{\mathrm{v}} /$ $\mathrm{F}_{\mathrm{m}}$ : The Maximal Photochemical Efficiency; ETR: The Apparent Electron Transport Rates; NPQ: The Nonphotochemical Quenching; qP: The Photochemical Quenching; Chl: Chlorophyll Content; MDA: Malondialdehyde Content; SOD: Superoxide Dismutase Activity; POD: Peroxidase Activity; CAT: Catalase Activity
\end{abstract}

\section{Introduction}

Salinity is one of the most important environmental factors that negatively affect plant yield and quality [1]. Excessive soil salinity is caused by not only mine in natural processes but also irrigating saline water [2]. Salt stress interferes in different metabolic processes and leads to an imbalance of ion and water homeostasis, which finally resulted in the chlorosis and growth retardation and even plant death [3]. Salt stress also alters photosynthesis rate and, secondary metabolites, and disturbs the metabolism of Calvin cycle and antioxidant enzymes $[4,5]$.

The oxidative stress induced by salt is known to produce abnormally high levels of the reactive oxygen species (ROS), which causes oxidative damage of lipids, proteins and nucleic acids through the disruption of normal cellular metabolism [6,7]. Plants have developed a series of defense strategies to mitigate the oxidative damage initiated by ROS. Among the defense strategies, antioxidative enzymes, such as superoxide dismutase (SOD, EC 1.15.1.1), peroxidase (POD, EC 1.11.1.7), catalase (CAT,

*Corresponding author: Haipeng Guo, School of Marine Sciences, Ningbo University, Ningbo 315211, China, E-mail: guohaipeng@nbu.edu.cn;

Jianhong Zhang, Academy of Agricultural Sciences, Ningbo City, Ningbo 315040, China, E-mail: nbjianhong@163.com

Received: March 26, 2018; Accepted: May 14, 2018; Published online: May 16, 2018

Citation: Hong C, Zheng B, Guo H, et al. (2018) Salt Stress Induces Shoot Formation and Physiological and Biochemical Changes in Miscanthus sacchariflorus. J Plant Biotechnol Res 1(1):16-25

Copyright: (c) 2018 Hong C, et al. This is an open-access article distributed under the terms of the Creative Commons Attribution License, which permits unrestricted use, distribution, and reproduction in any medium, provided the original author and source are credited. 
1.11.1.6), ascorbate peroxidase (APX, 1.11.1.1) and glutathione reductase (GR, EC 1.6.4.2), play an important role in scavenging ROS by a series of complex reactions $[8,9]$. Many previous studies reported that salt tolerance is most associated with the activities of these enzymes in plants $[6,7,10,11]$.

Miscanthus is grown worldwide as an important bioenergy crop with their fast growth and high biomass production. The responses of Miscanthus to abiotic stresses have been studied on heavy metals [12,13], low temperature [14] and drought $[15,16]$. However, it is known little about the responses of dry matter accumulation and photosynthesis of Miscanthus to salt stress. Therefore, the aims of this study are (1) To evaluate the effects of salt stress on plant growth, photosynthesis and the activity of anti-oxidative enzymes and lipid peroxidation, (2) To understand the relationship between dry matter accumulation and photosynthesis and (3) To uncover what are determinants for physiological and biochemical mechanisms of $M$. sacchariflorus to salt tolerance.

\section{Materials and Methods}

\section{Plant material and culture conditions}

Cultures of $M$. sacchariflorus were initiated from mature seeds which were collected from the Daming Mountain Scenic Spot in Lin'an, Zhejiang Province, in October 2013. Seeds were soaked in water for $2 \mathrm{~h}$, rinsed in $10 \%$ liquid dishwasher detergent, surface-sterilized in $70 \%$ ethanol for $30 \mathrm{~s}$, and rinsed with sterile water 3-4 times. Then seeds were planted on commercial potting mix in plastic trays and allowed to germinate in a growth chamber. The seedlings after germination for 4 weeks were transferred to hydroponic cultures supplied with half strength of Hoagland nutrient solution ( $\mathrm{pH}$ 6.0). Half-strength Hoagland nutrient solution was used containing the following macronutrients in mM: $\mathrm{KNO}_{3}, 2.5 ; \mathrm{Ca}\left(\mathrm{NO}_{3}\right)_{2} \cdot 4 \mathrm{H}_{2} \mathrm{O}, 2.5 ; \mathrm{MgSO}_{4} \cdot 7 \mathrm{H}_{2} \mathrm{O}, 1.0$; $\mathrm{NH}_{4} \mathrm{H}_{2} \mathrm{PO}_{4}, 0.5$, and the following micronutrients in $\mu \mathrm{M}$ : $\mathrm{CuSO}_{4} \cdot 5 \mathrm{H}_{2} \mathrm{O}, 0.5 ; \mathrm{ZnSO}_{4} \cdot 7 \mathrm{H}_{2} \mathrm{O}, 1.0 ; \mathrm{MnCl}_{2}, 1.25 ; \mathrm{H}_{3} \mathrm{BO}_{3}$, 7.5; $\left(\mathrm{NH}_{4}\right)_{6} \mathrm{Mo}_{7} \mathrm{O}_{24}, 0.25$ and NaFeEDTA 50. To ensure proper growth, the solutions were renewed every week. Following a 4-week hydroponic growth, the seedlings were subjected to $\mathrm{NaCl}$ treatments of $0,50,100$ and 200 $\mathrm{mM}$. Each treatment was replicated three times and each replicate included eight seedlings. The entire experiment was conducted under light conditions $\left(1200 \mu \mathrm{mol} \mathrm{m} \mathrm{m}^{-2} \mathrm{~s}^{-1}\right.$, $16 / 8 \mathrm{~h}$ light/dark period) at $25{ }^{\circ} \mathrm{C}$ and $65 \%$ relative humidity.

\section{Determination of plant growth}

After $14 \mathrm{~d}$ treatment, eight plants per treatment were randomly harvested. Harvested plants were divided into the culm, leaf and hypogeal parts (rhizome and roots).
The number of culm and shoot was recorded. Plant height was recorded with the length of the highest culm deprived from leaf as well as the longest root length. Roots were generously rinsed with tap water to remove $\mathrm{NaCl}$ deposits. For dry weight determination, all plant parts were dried at $75^{\circ} \mathrm{C}$ to constant weight.

\section{Determination of photosynthetic parameters}

$\mathrm{P}_{\mathrm{N}}$ was measured by using a portable photosynthesis system (Portable Photosynthesis System LI 6400, LI-COR, Lincoln, NE, USA) with red/blue LED light source with a $6 \mathrm{~cm}^{2}$ clamp-on leaf chamber. Fully expanded youngest leaves of 3-5 plants per treatment were used for measurements. Samplings were measured after gas-exchange parameters reached the steady state. Gas exchange parameters were calculated according to Von Caemmerer and Farquhar [17]. The results are the means of at least three measurements. All measurements were made in a temperature-controlled room $\left[30 \pm 2{ }^{\circ} \mathrm{C}, 16 / 8 \mathrm{~h}\right.$ light/ dark period, $1000-1200 \mu \mathrm{mol}$ (photon) $\mathrm{m}^{-2} \mathrm{~s}^{-1}$ and $65 \%$ relative humidity]. Once $\mathrm{P}_{\mathrm{N}}$ was obtained, fresh leaf, shoot and root were collected from plant and immediately frozen in liquid nitrogen and stored at $-80{ }^{\circ} \mathrm{C}$ for chlorophyll, proline, malondialdehyde (MDA) content and enzyme activity analysis.

\section{Determination of chlorophyll fluorescence pa- rameters}

Chlorophyll fluorescence parameters and images were obtained using a FluorImager chlorophyll fluorescence imaging system (Technologica Ltd., Colchester, UK). The 10-d-old hydroponically seedlings were grown in $1 / 2$ Hoagland nutrient solution ( $\mathrm{pH} 6.0$ ) or $1 / 2$ Hoagland nutrient solution containing 50,100 or $200 \mathrm{mM}$ $\mathrm{NaCl}$ for $5 \mathrm{~d}$, respectively, then transferred in 96-well microtiter plate. Following a 20 min dark adaptation, the minimal $\left(\mathrm{F}_{0}\right)$ level of fluorescence was measured at very weak measuring pulses, while the maximal $\left(\mathrm{F}_{\mathrm{m}}\right)$ level of fluorescence was measured during an $800 \mathrm{~ms}$ pulse at a PPDF of approximately $6000 \mu \mathrm{mol} \mathrm{m} \mathrm{m}^{-2} \mathrm{~s}^{-1}$. The maximal photochemical efficiency $\left(\mathrm{F}_{\mathrm{v}} / \mathrm{F}_{\mathrm{m}}\right)$ of PSII was expressed as the ratio $\mathrm{F}_{\mathrm{v}} / \mathrm{F}_{\mathrm{m}}=\left(\mathrm{F}_{\mathrm{m}}-\mathrm{F}_{0}\right) / \mathrm{F}_{\mathrm{m}}$. Then the plants were light-adapted at the PPFD of $1000 \mu \mathrm{mol} \mathrm{m} \mathrm{m}^{-2} \mathrm{~s}^{-1}$ for 20 min before measurements of the yield of effective photochemical quantum [Y(II)], the photochemical (qP) and nonphotochemical (NPQ) quenching of chlorophyll fluorescence. And the apparent electron transport rates (ETR) were calculated according to the formula: ETR = $\mathrm{Y}(\mathrm{II}) \times \mathrm{PPFD} \times 0.84 \times 0.4$.

\section{Determination of chlorophyll, proline, malondi- aldehyde (MDA) content}

Chlorophyll was extracted in 95\% ethanol and characterized by the method of Hong, et al. [18]. Proline ac- 
Citation: Hong C, Zheng B, Guo H, et al. (2018) Salt Stress Induces Shoot Formation and Physiological and Biochemical Changes in Miscanthus sacchariflorus. J Plant Biotechnol Res 1(1):16-25

cumulation was determined as described by Köşkeroğlu and Tuna [19]. The proline concentration was calculated using proline standards $(0-50 \mathrm{mg} / \mathrm{ml})$ in the identical manner. The content of MDA was determined using the thiobarbituric acid reaction, following the method of Madhava Rao and Sresty [20], and calculated from the absorbance at $532 \mathrm{~nm}$. The measurements were corrected for non-specific turbidity by subtracting the absorbance at $600 \mathrm{~nm}$, and the results expressed as $\mu \mathrm{mol} \mathrm{g} \mathrm{g}^{-1}$ flesh weight (FW).

\section{Determination of SOD, CAT and POD activities}

Five grams of frozen leaf, shoot or root were ground at $4{ }^{\circ} \mathrm{C}$ in a mortar with $5 \mathrm{ml}$ of $50 \mathrm{mM}$ phosphate buffer solution ( $\mathrm{pH} 7.8$ ) containing $1 \%$ polyethylene pyrrole (PVP). The homogenate was centrifuged at 10,000 rpm at $4{ }^{\circ} \mathrm{C}$ for $30 \mathrm{~min}$. Supernatants were collected for measuring enzyme activities.

Superoxide dismutase (E.C.1.15.1.1) activity was estimated spectrophotometrically as the inhibition of photochemical reduction of NBT at $560 \mathrm{~nm}$, a minor modification of the method of Köşkeroğlu and Tuna [19]. The reaction mixture consisted of $0.3 \mathrm{~mL}$ each of $0.75 \mathrm{mM}$ NBT, $130 \mathrm{mM}$ methionine, $0.1 \mathrm{mM}$ EDTA-Na, 0.02
$\mathrm{mM}$ Riboflavin, and sterilized water and $1 \mathrm{~mL}$ of $50 \mathrm{mM}$ $\mathrm{Na}$-phosphate buffer ( $\mathrm{pH}$ 7.8). The reaction was initiated by adding $0.1 \mathrm{~mL}$ of the enzyme extract and carried out for $10 \mathrm{~min}$ at $25^{\circ} \mathrm{C}$ under a light intensity of about $300 \mathrm{mmol}^{-1} \mathrm{~m}^{-2} \mathrm{~s}^{-1}$. One unit of SOD was defined as that which inhibited photo reduction of NBT to $50 \%$.

Catalase (E.C.1.11.1.6) activity was detected according to the method of Cakmak and Marschner [21] with a slight modification (1992). The reaction mixture, in a total volume of $3 \mathrm{~mL}$, contained $1.5 \mathrm{~mL}$ of $50 \mathrm{mM}$ sodium phosphate buffer ( $\mathrm{pH} 7.8$ ) and $0.3 \mathrm{~mL}$ of $0.1 \mathrm{M} \mathrm{H}_{2} \mathrm{O}_{2}$. The reaction was initiated by adding $0.1 \mathrm{~mL}$ of the enzyme extract, and the activity determined by measuring the initial rate of disappearance of $\mathrm{H}_{2} \mathrm{O}_{2}$ at $240 \mathrm{~nm}$.

Peroxidase (E.C.1.11.1.7) activity was assayed using the method of Medina-Pérez [22]. The reaction mixture contained $50 \mathrm{mM}$ potassium phosphate buffer $\mathrm{pH}$ 6.0, 10 $\mathrm{mM} \mathrm{H}_{2} \mathrm{O}_{2}$ solution, $20 \mathrm{mM}$ guaiacol and $0.1 \mathrm{ml}$ of crude extract (Chance and Maehly 1955). The reaction was started by adding at the same time $\mathrm{H}_{2} \mathrm{O}_{2}$ and guaiacol solution and the activity was determined by monitoring the increase of absorbance at $470 \mathrm{~nm}$, as a result of guaiacol oxidation.

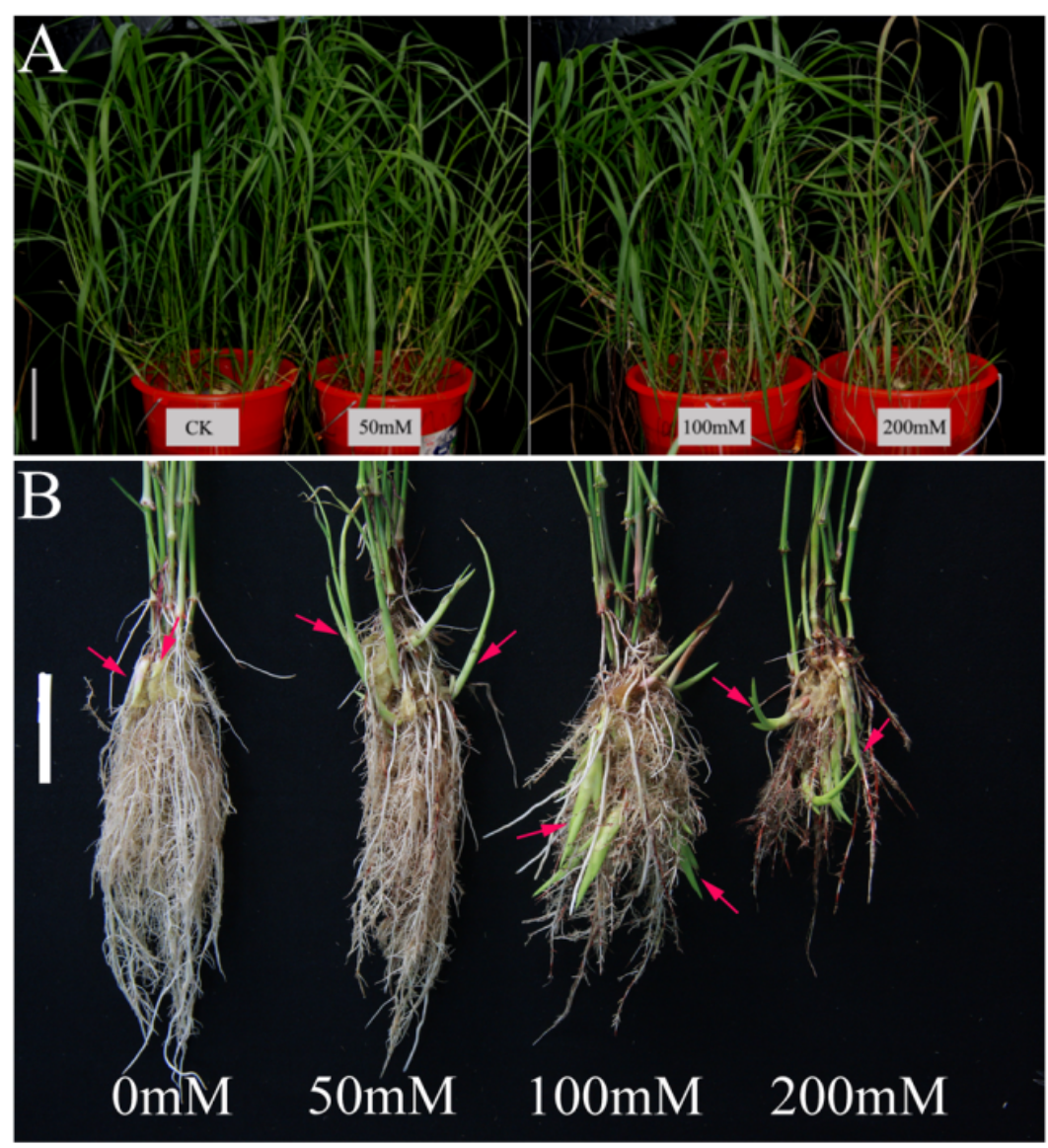

Figure 1: Effects of the different $\mathrm{NaCl}$ concentrations on the growth of $M$. sacchariflorus, (A) Growth characteristics of $M$. sacchariflorus seedlings; (B) Enhanced adventitious shoot formation; (A) Bar $=15 \mathrm{~cm}$; (B) Bar $=3 \mathrm{~cm}$. 
Citation: Hong C, Zheng B, Guo H, et al. (2018) Salt Stress Induces Shoot Formation and Physiological and Biochemical Changes in Miscanthus sacchariflorus. J Plant Biotechnol Res 1(1):16-25

Table 1: Effects of $\mathrm{NaCl}$ treatment on growth and dry weight of $M$. sacchariflorus plants.

\begin{tabular}{|l|l|l|l|l|l|l|l|}
\hline $\begin{array}{l}\mathrm{NaCl} \\
(\mathbf{m m o l} / \mathrm{L})\end{array}$ & $\begin{array}{l}\text { Plant height } \\
(\mathbf{c m})\end{array}$ & $\begin{array}{l}\text { Root length } \\
(\mathbf{c m})\end{array}$ & $\begin{array}{l}\text { Shoot number } \\
\text { (per plant) }\end{array}$ & $\begin{array}{l}\text { Culm number } \\
\text { (per plant) }\end{array}$ & $\begin{array}{l}\text { Dry weight (g per plant) } \\
\text { Aboveground Underground } \\
\text { part }\end{array}$ & $\begin{array}{l}\text { Root-shoot } \\
\text { part }\end{array}$ & \\
\hline 0 & $113.67 \pm 7.99 \mathrm{a}$ & $19.55 \pm 0.64 \mathrm{a}$ & $4.1 \pm 0.6 \mathrm{c}$ & $5.0 \pm 1.7 \mathrm{a}$ & $9.34 \pm 1.73 \mathrm{a}$ & $2.49 \pm 0.47 \mathrm{a}$ & $0.29 \pm 0.03 \mathrm{~b}$ \\
\hline 50 & $109.50 \pm 9.50 \mathrm{a}$ & $17.58 \pm 1.18 \mathrm{~b}$ & $7.1 \pm 1.3 \mathrm{~b}$ & $3.8 \pm 1.1 \mathrm{a}$ & $8.24 \pm 0.92 \mathrm{~b}$ & $2.06 \pm 0.28 \mathrm{~b}$ & $0.30 \pm 0.06 \mathrm{~b}$ \\
\hline 100 & $100.42 \pm 7.80 \mathrm{~b}$ & $13.75 \pm 1.44 \mathrm{c}$ & $9.3 \pm 1.8 \mathrm{a}$ & $4.0 \pm 1.4 \mathrm{a}$ & $7.83 \pm 1.18 \mathrm{~b}$ & $2.32 \pm 0.90 \mathrm{a}$ & $0.32 \pm 0.04 \mathrm{a}$ \\
\hline 200 & $88.50 \pm 4.65 \mathrm{c}$ & $12.90 \pm 1.03 \mathrm{c}$ & $7.4 \pm 2.6 \mathrm{~b}$ & $4.8 \pm 2.3 \mathrm{a}$ & $3.09 \pm 0.46 \mathrm{c}$ & $0.71 \pm 0.14 \mathrm{c}$ & $0.23 \pm 0.05 \mathrm{c}$ \\
\hline
\end{tabular}

Data are means $\pm S D(n=6)$; Different letters indicate a significant difference at $p<0.05$.
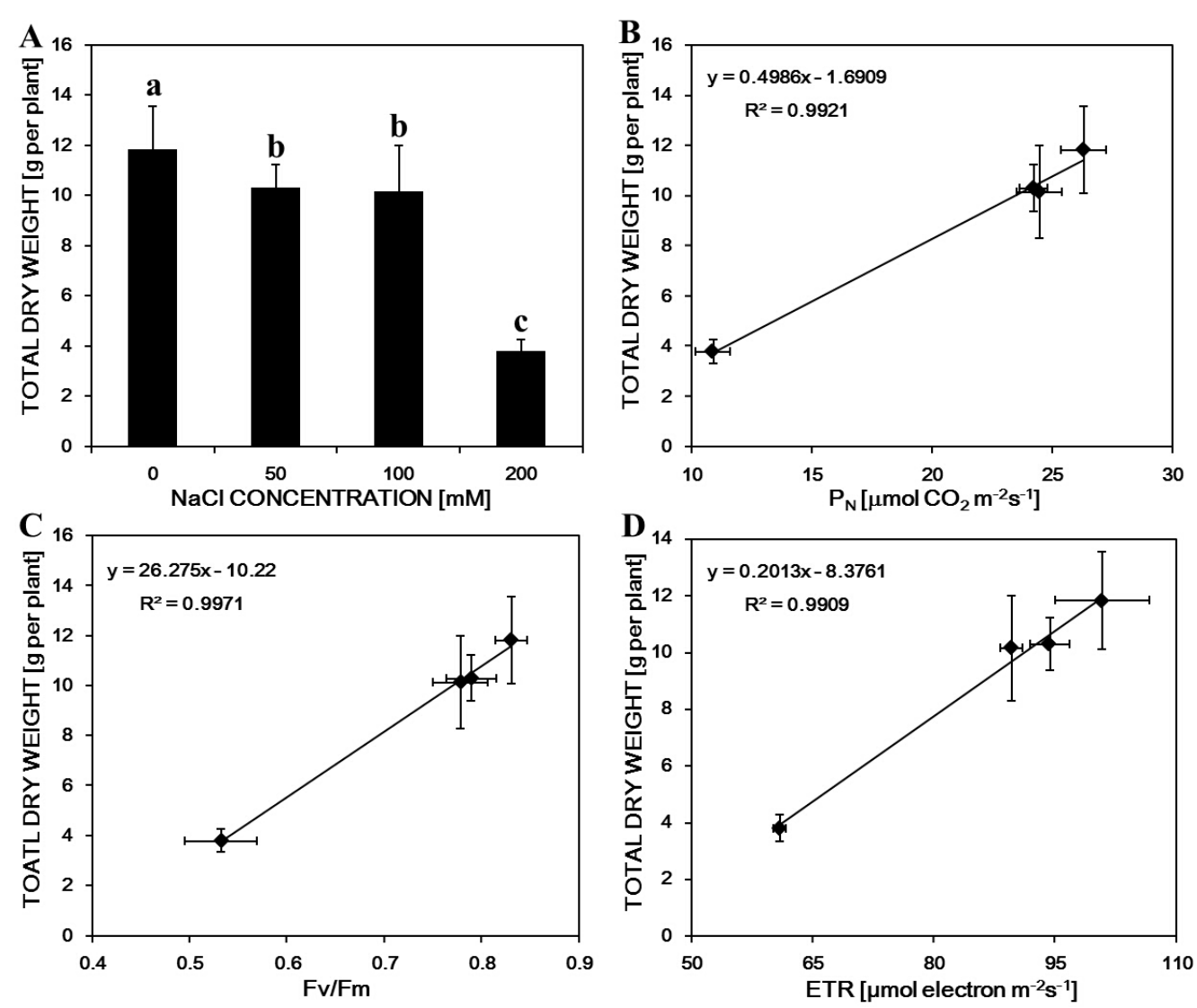

Figure 2: Effects of the different $\mathrm{NaCl}$ concentrations on plant total weight $(\mathrm{A})$ and relationships between the total dry weight and net photosynthesis rate $\left(P_{N}, B\right)$, the maximal photochemical efficiency $\left(F_{v} / F_{m}, C\right)$ and the apparent electron transport rates $(E T R, D)$ in M. sacchariflorus. Data are mean $\pm S D(n=3)$. Different letters indicate a significant difference at $p<0.05$.

\section{Statistical analysis}

All data were evaluated by one-way ANOVA using SPSS 6.0.1 for Windows as well as the least significance difference and Tukey's honestly significant difference tests.

\section{Resullits}

Growth parameters were taken as a measure of the growth of $M$. sacchariflorus plants, and Table 1 showed the dose-dependent effect of $\mathrm{NaCl}$ treatment on plant growth (Figure 1A). All NaCl stress reduced $M$. sacchariflorus growth. Especially treatment with $200 \mathrm{mM} \mathrm{NaCl}$, plant height and root length were decreased by $22 \%$ and $34 \%$ respectively. Interestingly, salt stress triggered largely new shoot formation in spite of not significant in- fluence the number of culm (Figure $1 \mathrm{~B}$ and Table 1). The dry weight of $\mathrm{NaCl}$-treated shoot and root was much lower than that of controls. Those were decreased by $66.9 \%$ and $71.5 \%$, respectively, with the further increase of $\mathrm{NaCl}$ concentration of $200 \mathrm{mM}$. The total dry matter accumulation in salt-treated plants was also significantly decreased in comparison with the control plant (Figure 2A). However, all treated plants significantly promoted new shoot formation. Among those, treatment with $100 \mathrm{mM} \mathrm{NaCl}$ induced markedly new shoot formation and the numbers increased to 2.3 times as compared to the control group. Perhaps, a marked increase of shoot formation in those $\mathrm{NaCl}$ treatments compensated for the growth inhibition by $\mathrm{NaCl}$. Root/shoot ratios were promoted under moderate $\mathrm{NaCl}$ treatments but inhibited by $21 \%$ in $200 \mathrm{mM}$ $\mathrm{NaCl}$ treatment as compared with control. 
Citation: Hong C, Zheng B, Guo H, et al. (2018) Salt Stress Induces Shoot Formation and Physiological and Biochemical Changes in Miscanthus sacchariflorus. J Plant Biotechnol Res 1(1):16-25

Table 2: Effects of $\mathrm{NaCl}$ treatment on net photosynthesis rate $\left(\mathrm{P}_{\mathrm{N}}\right)$, stomata conductance $\left(\mathrm{g}_{\mathrm{s}}\right)$, intercellular $\mathrm{CO}_{2}$ concentration $\left(\mathrm{C}_{\mathrm{i}}\right)$ and transpiration rate $(E)$ of $M$. sacchariflorus plants.

\begin{tabular}{|l|l|l|l|l|}
\hline $\mathbf{N a C l}(\mathbf{m m o l} / \mathbf{L})$ & $\mathbf{P}_{\mathbf{N}}\left(\boldsymbol{\mu m o l ~} \mathbf{C O}_{2} \mathbf{~ m}^{-2} \mathbf{s}^{-1}\right)$ & $\mathbf{g}_{\mathbf{s}}\left(\mathbf{m o l ~ H} \mathbf{O} \mathbf{~ m}^{-2} \mathbf{s}^{-1}\right)$ & $\mathbf{C}_{\mathbf{i}}\left(\boldsymbol{\mu m o l ~ C O} \mathbf{~ m o l}^{-1}\right)$ & $\mathbf{E}\left(\mathbf{m m o l ~ H}_{2} \mathbf{O} \mathbf{~ m}^{-2} \mathbf{s}^{-1}\right)$ \\
\hline 0 & $26.32 \pm 0.94 a$ & $0.2297 a$ & $205.00 \pm 12.00 a$ & $4.90 \pm 0.18 \mathrm{a}$ \\
\hline 50 & $24.23 \pm 0.58 \mathrm{~b}$ & $0.1893 \pm 0.01 \mathrm{~b}$ & $193.67 \pm 11.37 \mathrm{ab}$ & $4.37 \pm 0.29 \mathrm{~b}$ \\
\hline 100 & $24.47 \pm 0.95 \mathrm{~b}$ & $0.1716 \pm 0.01 \mathrm{c}$ & $174.67 \pm 27.30 \mathrm{~b}$ & $4.09 \pm 0.12 \mathrm{~b}$ \\
\hline 200 & $10.90 \pm 0.72 \mathrm{c}$ & $0.0680 \mathrm{~d}$ & $177.89 \pm 16.38 \mathrm{ab}$ & $1.85 \pm 0.27 \mathrm{a}$ \\
\hline
\end{tabular}

Data are means $\pm S D(n=3)$; Different letters indicate a significant difference at the $p<0.05$.

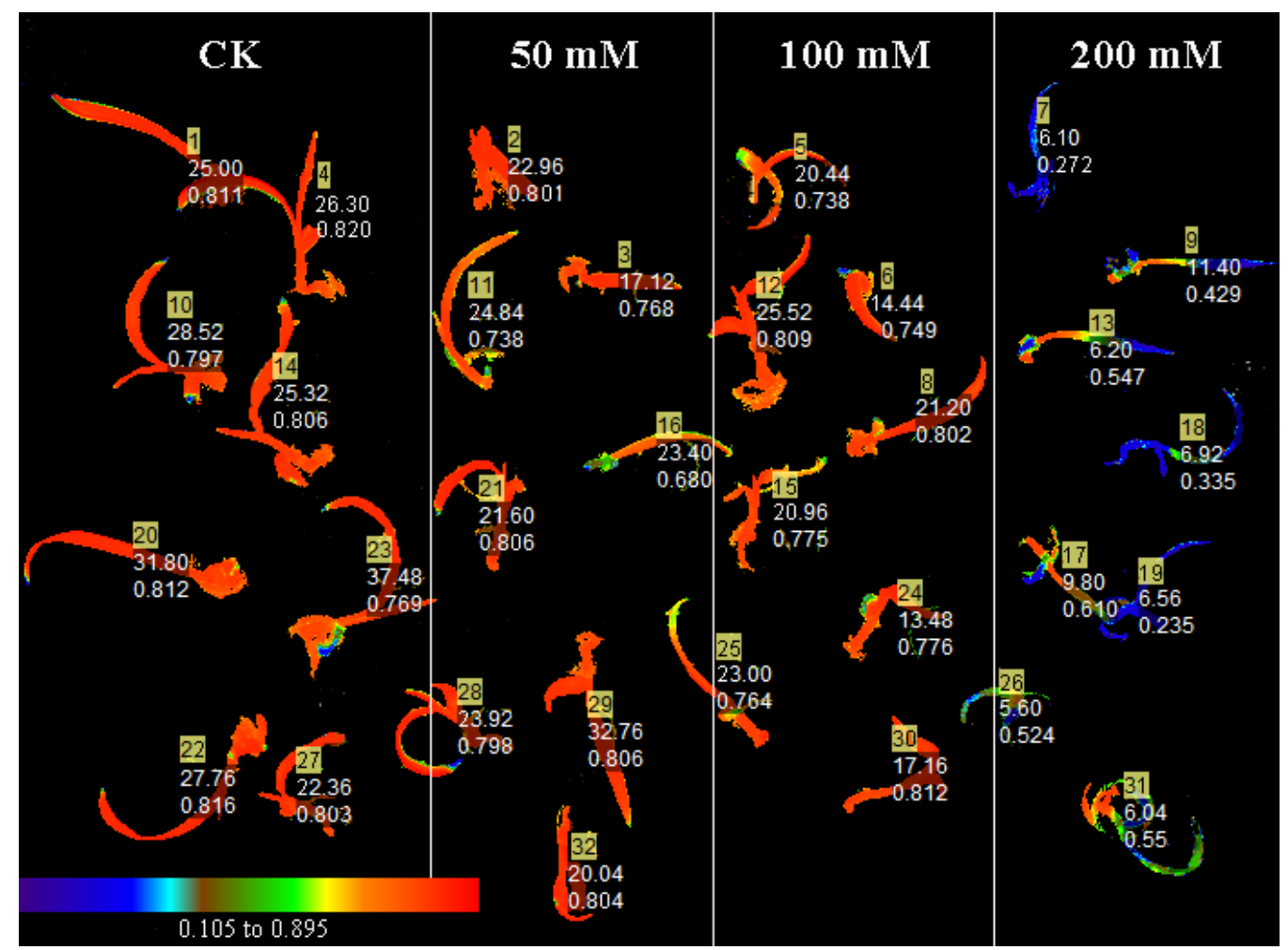

Figure 3: Effects of the different $\mathrm{NaCl}$ concentrations on $\mathrm{F}_{\sqrt{ }} / \mathrm{F}_{\mathrm{m}}$ of whole plant seedlings using chlorophyll fluorescence imaging.

The growth inhibition of $M$. sacchariflorus plants was accompanied by a significant decrease in net photosynthesis rate $\left(\mathrm{P}_{\mathrm{N}}\right)$, which was about 2.5 times reduced at the highest $\mathrm{NaCl}$ concentration in comparison with control plant (Table 2). Interestingly, $\mathrm{P}_{\mathrm{N}}$ in leaves showed no significant difference between 50 and $100 \mathrm{mM} \mathrm{NaCl}$, and they were only lower by $8 \%$ and $7 \%$ than that in the control group, respectively. Those indicated the higher resistance of $M$. sacchariflorus to salt stress. The stomata conductance $\left(\mathrm{g}_{\mathrm{s}}\right)$, intercellular $\mathrm{CO}_{2}$ concentration $\left(\mathrm{C}_{\mathrm{i}}\right)$ and transpiration rate $(\mathrm{E})$ were also markedly reduced with the increasing $\mathrm{NaCl}$ stress. Especially $\mathrm{g}_{\mathrm{s}}$ in the treatment with $200 \mathrm{mM} \mathrm{NaCl}$ was only $0.06, \mathrm{P}_{\mathrm{N}}$ decreased by $70 \%$ less than that in the control group.

To explore the chlorophyll fluorescence change after short time salt treatments, we used a FluorImager chlorophyll fluorescence imaging system (Technologica Ltd., Colchester, UK) to take the imaging of chlorophyll fluorescence of the plant seedling. The picture was shown in Figure 3 and some of chlorophyll fluorescence parameters were shown in Table 3. Only exposure of 10-d-old plants to $\mathrm{NaCl}$ treatment for $5 \mathrm{~d}$ led to significant decrease in ETR and $\mathrm{qP}$ with increasing $\mathrm{NaCl}$ concentrations, where in comparison to control ETR was reduced to 93.6, 88.9 and $60.4 \%$ "and qP". to $91.6,84.4$ and $73.4 \%$ with increasing $\mathrm{NaCl}$ concentration, respectively. $\mathrm{F}_{\mathrm{v}} / \mathrm{F}_{\mathrm{m}}$ and NPQ were no significant difference in M. sacchariflorus between 50 and $100 \mathrm{mM} \mathrm{NaCl}$ treatment, but the highest $\mathrm{NaCl}$ concentration $(200 \mathrm{mM})$ resulted in reduction of $\mathrm{F}_{\mathrm{v}} / \mathrm{F}_{\mathrm{m}}$ and $\mathrm{NPQ}$ by $33.7 \%$ and $43.6 \%$ after $5 \mathrm{~d}$ salt treatment. Those meant that the different chlorophyll fluorescence parameters exhibited the different responses to salt concentrations.

Analyzing the relationship between dry weight and photosynthetic parameter clearly showed that all $\mathrm{P}_{\mathrm{N}}, \mathrm{F}_{\mathrm{v}} /$ $\mathrm{F}_{\mathrm{m}}$ and ETR were extremely significantly positively related to total dry weight of plants $\left(\mathrm{R}^{2}>0.99\right)$ under the salt treatment, indicating that the decrease in dry matter accumulation was due to lower photosynthesis resulted from salt stress (Figure 2B, Figure 2C and Figure 2D).

The levels of proline and MDA often are used as in- 
Citation: Hong C, Zheng B, Guo H, et al. (2018) Salt Stress Induces Shoot Formation and Physiological and Biochemical Changes in Miscanthus sacchariflorus. J Plant Biotechnol Res 1(1):16-25

Table 3: Change in chlorophyll fluorescence parameters, $F_{v} / F_{m}$, ETR, NPQ and qP under 0,50, 100 and $200 \mathrm{mM} \mathrm{NaCl} \mathrm{stress} \mathrm{for}$ $5 \mathrm{~d}$ of $M$. sacchariflorus plants.

\begin{tabular}{|c|c|c|c|c|}
\hline $\mathrm{NaCl}(\mathrm{mmol} / \mathrm{L})$ & $\mathbf{F}_{\mathrm{v}} / \mathbf{F}_{\mathrm{m}}$ & ETR & NPQ & $\mathbf{q P}$ \\
\hline 0 & $0.803 \pm 0.016 a$ & $100.8 \pm 5.85 a$ & $2.848 \pm 0.044 a$ & $0.557 \pm 0.125 a$ \\
\hline 50 & $0.789 \pm 0.026 a$ & $94.3 \pm 2.43 b$ & $2.640 \pm 0.080 a$ & $0.510 \pm 0.121 b$ \\
\hline 100 & $0.778 \pm 0.028 a$ & $89.6 \pm 1.38 b$ & $2.600 \pm 0.123 a$ & $0.470 \pm 0.006 c$ \\
\hline 200 & $0.532 \pm 0.037 b$ & $60.9 \pm 0.79 c$ & $1.606 \pm 0.224 b$ & $0.409 \pm 0.101 d$ \\
\hline
\end{tabular}

Data are mean $\pm S D(n=8)$; Different letters indicate a significant difference at $p<0.05$.
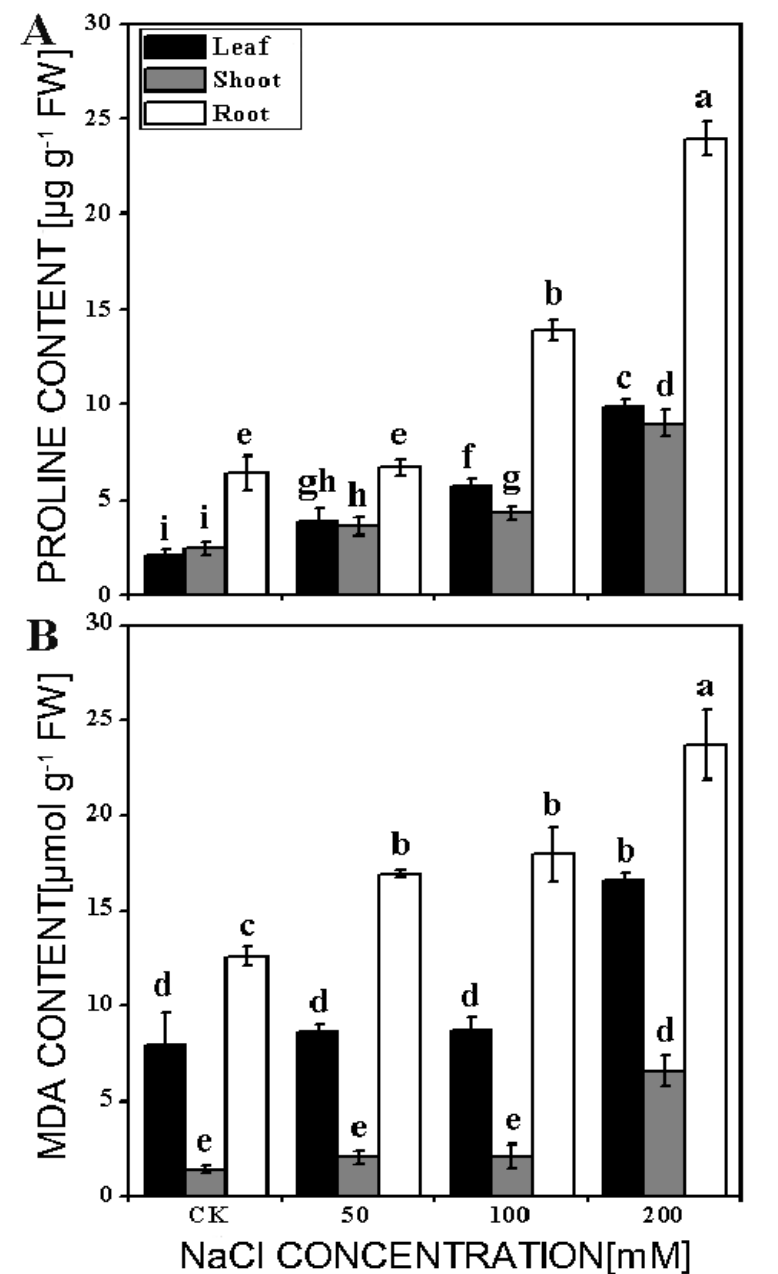

Figure 4: Effects of the different $\mathrm{NaCl}$ concentrations on proline (A) and MDA contents $(B)$ of $M$. sacchariflorus. Data are mean $\pm S D(n=3)$. Different letters indicate a significant difference at $p<0.05$.

dexes for damage of tissue under stresses. Our results showed that the contents of proline and MDA of the leaf, shoot and root in different treatments were all enhanced with the increase in $\mathrm{NaCl}$ concentrations. Proline contents were much higher in root than that in leaf or shoot (Figure 4A) and shoot exhibited relative lower increase after salt treatment. In three salt concentrations, proline contents in the leaf were 1.8, 2.7 and 4.7 times of the control $(2.1 \mu \mathrm{g} / \mathrm{g})$, in shoot $1.5,1.7$ and 3.6 times of control $(2.5 \mu \mathrm{g} / \mathrm{g})$ and in root 1.1, 2.2 and 3.7 times of the control $(6.4 \mu \mathrm{g} / \mathrm{g})$, respectively. The responses of MDA in leaf and shoot subjected to salt stress were variable (Figure
4B). MDA contents were significantly increased in the leaf, shoot and root treated with $200 \mathrm{mM} \mathrm{NaCl}$. However, the level of MDA was not significantly different in leaf, shoot treated with 50 and $100 \mathrm{mM} \mathrm{NaCl}$. The results clearly showed that the new shoots accumulated much less MDA, suggesting that the salt-induced injury of the shoots was less.

To understand whether the salt-tolerance in leaf, new shoot and root of $M$. sacchariflorus plants was relevant to antioxidant enzyme, SOD, POD and CAT activities were determined under different concentrations of $\mathrm{NaCl}$. Effects of salt on antioxidant enzyme activities were different in different parts of M. sacchariflorus (Figure 5). The activity of SOD was markedly enhanced in all parts with increasing of $\mathrm{NaCl}$ concentrations, it increased by $90 \%, 69 \%$ and $127 \%$ in the leaf, new shoot and root under the treatment of $200 \mathrm{mM} \mathrm{NaCl}$, respectively (Figure $5 \mathrm{~A})$. Whereas the activity of POD was significantly rose only in shoot with the increase of $12 \%, 36 \%$ and $52 \%$ under three salt concentrations, respectively, or in leaf and root with the increase of $25 \%$ and $24 \%$ in $200 \mathrm{mM} \mathrm{NaCl}$ concentration, respectively (Figure 5B). For the CAT activity, $\mathrm{NaCl}$ exposure did not generate a significant difference from the control in shoot, except the highest $\mathrm{NaCl}$ concentration, with the increment of $124 \%$. However, the CAT activity was significantly increased in leaf and root in all $\mathrm{NaCl}$ levels (Figure $5 \mathrm{C}$ ). The extremely significantly $\left(\mathrm{R}^{2}>0.99\right)$ or significantly $\left(\mathrm{R}^{2}>0.93\right)$ curvilinearly correlation between shoot numbers and SOD, POD and CAT, respectively, showed that new shoots had higher capacity of resistance to oxidation under salt stress, which were of advantage to new shoot formation (Figure 6).

\section{Discussion}

Soil salinity is one of the most important factors limiting global crop production by interfering with essential physiological processes [23]. It causes harms to plants mainly in two ways: Firstly, excessive salt in soil leads to decrease the water potential, which results in water stress in plants; secondly, accumulation of some specific ions causes nutritional imbalance [2]. Plants have evolved various mechanisms to cope with these detrimental damages [24]. Salt stress exhibited a significant decrease in the plant height, root length and dry biomass of M. saccha- 

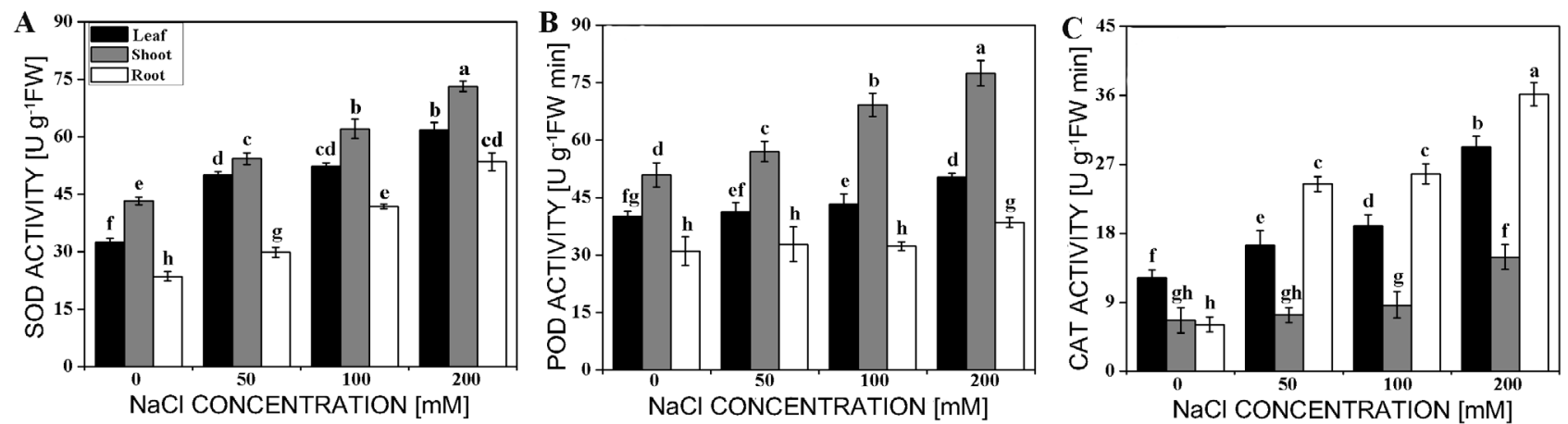

Figure 5: Effects of the different $\mathrm{NaCl}$ concentrations on SOD (A), POD (B) and CAT (C) of $M$. sacchariflorus. Data are mean $\pm S D(n=3)$. Different letters indicate a significant difference at $p<0.05$.
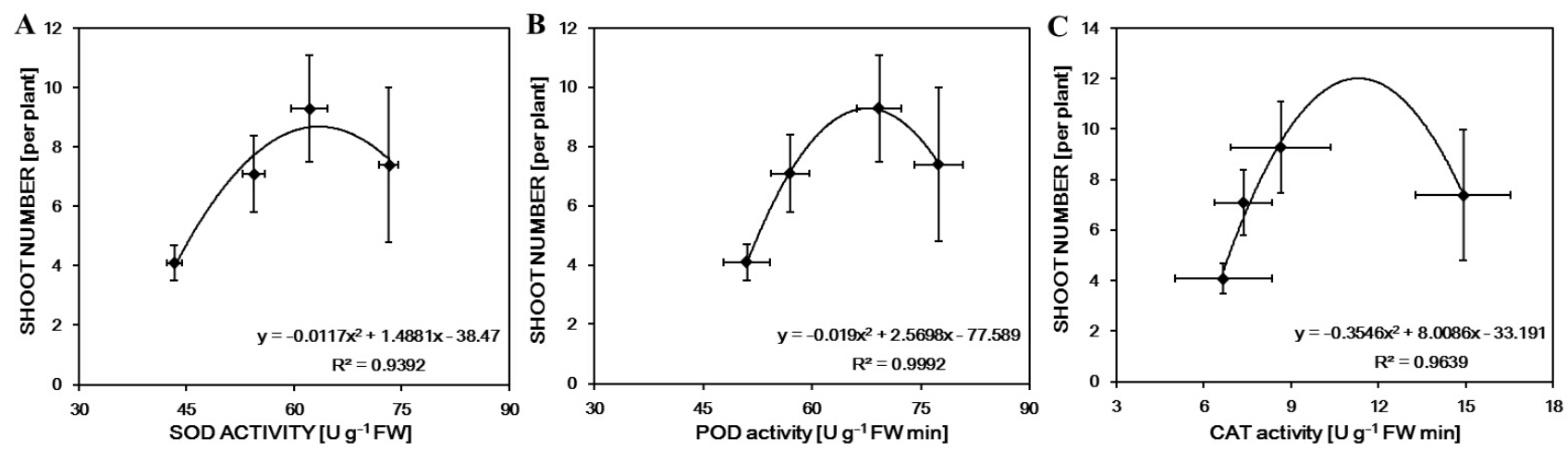

Figure 6: Relationships between shoot number per plant and SOD (A), CAT (B) and POD (C) in M. sacchariflorus.
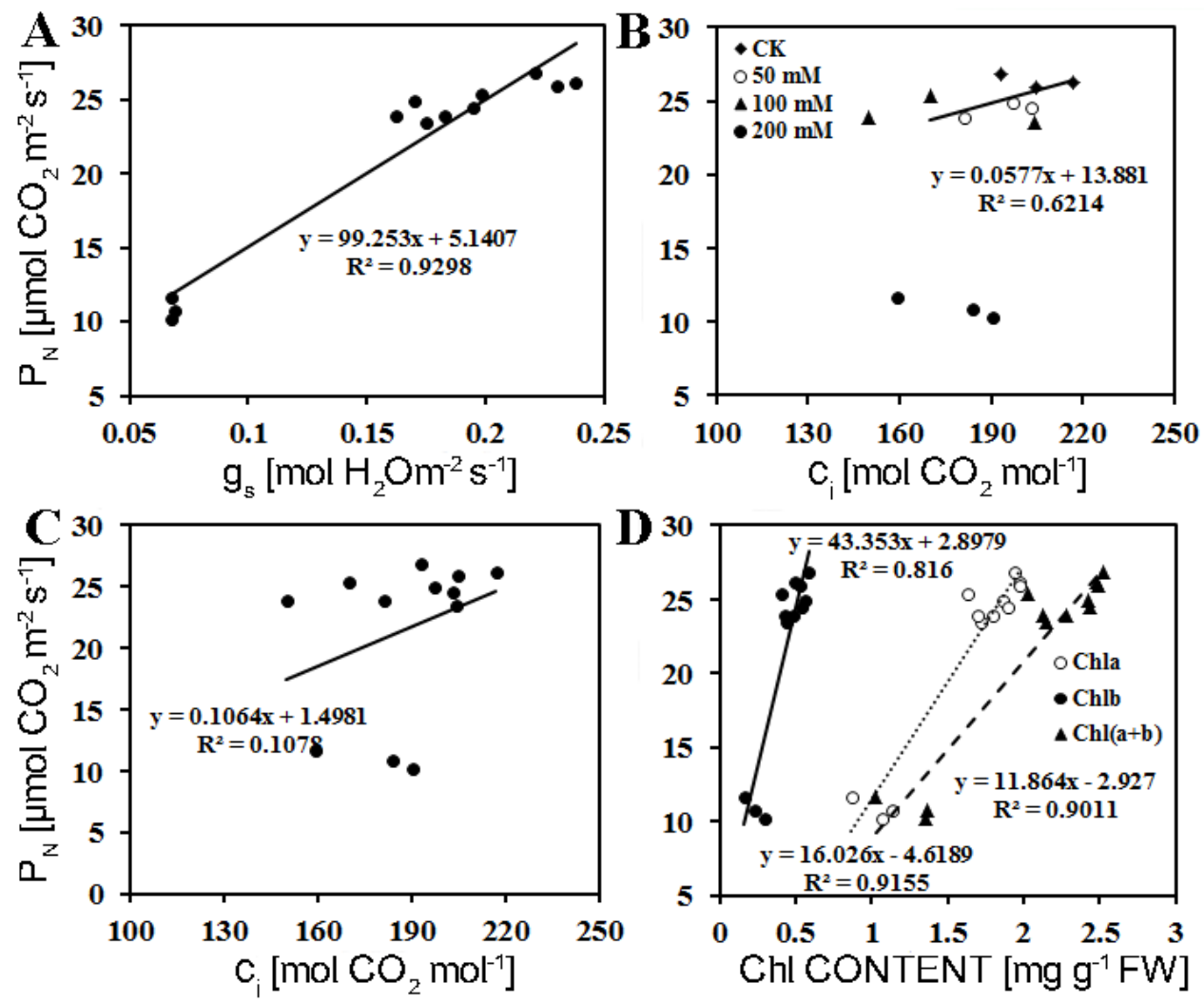

Figure 7: The correlation between the stomatal conductance $\left(g_{s}\right)(A)$, intercellular $\mathrm{CO}_{2}$ concentration $(\mathrm{ci}),(\mathrm{B}, \mathrm{C})$, the chlorophyll a $(\mathrm{Chl} \mathrm{a})$, chlorophyll b $(\mathrm{Chl} a)$, total chlorophyll $(\mathrm{Chl} \mathrm{a}+\mathrm{b})(\mathrm{C})$ and net photosynthesis rate $\left(\mathrm{P}_{\mathrm{N}}\right)$. 
riflorus plants, especially by the highest concentrations (200 mM) (Table 1). In addition, 50 and $100 \mathrm{mM} \mathrm{NaCl}$ treatments were able to maintain the total dry weight above $86 \%$, suggesting that $M$. sacchariflorus could withstand moderate salt stress (up to $100 \mathrm{mM} \mathrm{NaCl}$ ).

The decrease of $\mathrm{P}_{\mathrm{N}}$ under salt stress has been reported in many plants, including rice [25], and other plant species [26-28]. Decrease in $\mathrm{P}_{\mathrm{N}}$ of soybean was attributed to the closure of stoma, which decreased the intercellular $\mathrm{CO}_{2}$ concentration and depressed the rate of $\mathrm{CO}_{2}$ assimilation in the leaf $[29,30]$. Our results showed that $P_{N}, g_{s}$ and $\mathrm{Ci}$ were all decreased as the increase in $\mathrm{NaCl}$ concentrations. According to Farquhar and Sharkey' view $\mathrm{P}_{\mathrm{N}}$ is mainly limited by stomatal factor only when it is significantly positively linear correlation with either $g_{s}$ or $\mathrm{C}_{\mathrm{i}}$ [31]. Regression analysis indicated that $\mathrm{P}_{\mathrm{N}}$ was linearly relative to $\mathrm{G}_{\mathrm{s}}$ and $\mathrm{C}_{\mathrm{i}}$ at $\leqq 100 \mathrm{mM} \mathrm{NaCl}$, indicating that $\mathrm{P}_{\mathrm{N}}$ is mainly limited by stomatal factor (Figure $7 \mathrm{~A}$ and Figure $7 \mathrm{~B}$ ); while at $>100 \mathrm{mM} \mathrm{NaCl} \mathrm{P}_{\mathrm{N}}$ was only linearly relative to $G_{s}$, rather than $C_{i}$, indicating that $P_{N}$ is limited by non-stomatal factor (Figure $7 \mathrm{~A}$ and Figure $7 \mathrm{C}$ ). When carbon fixation is limited by ci due to lower $\mathrm{g}_{\mathrm{s}}$, NADPH produced by photosynthetic electron transport is superfluous if photochemical reaction keeps normal. Those phenomena often appear in the early stressed plants that depression of photosystem activities and photosynthetic electron transport rate is later than that of $\mathrm{P}_{\mathrm{N}}[29,30,32]$. Our results supported that conclusion. $\mathrm{F}_{\mathrm{v}} / \mathrm{F}_{\mathrm{m}}$ and $\mathrm{NPQ}$ were not significantly fallen upon $100 \mathrm{M} \mathrm{NaCl}$, while $\mathrm{P}_{\mathrm{N}}$ decreased significant in any concentration of salt (Table 2 and Table 3). The degrees of declination of ETR and $\mathrm{qP}$ were less in comparison with $\mathrm{P}_{\mathrm{N}}$, and the decrease in ETR and $\mathrm{qP}$ was slower than the $\mathrm{P}_{\mathrm{N}}$ (Table 3 ), which indicated that the activities of photosynthetic system and linearly photosynthetic electron transport were larger than those required in $\mathrm{CO}_{2}$ assimilation under salt stress. The excessive electron resulted in the production of excessive excitation energy in chloroplast, which causes oxidative stress through an increase in ROS, such as superoxide anion $\left(\mathrm{O}_{2}^{--}\right)$, hydrogen peroxide $\left(\mathrm{H}_{2} \mathrm{O}_{2}\right)$ and hydroxyl radicals (OH.) [4]. Under high light condition plant develops a serious protective reaction from damage by reactive oxygen species (ROS) that occurs via pseudo-cyclic photosynthetic electron transport under excessive light energy [33]. The water-water cycle in chloroplast plays a vital role in scavenging of ROS and dissipation of excess photons [34]. In addition, the decrease in $\mathrm{P}_{\mathrm{N}}$ was positively relative to $\mathrm{Chl}$ a $\left(\mathrm{R}^{2}=0.916, \mathrm{n}=12\right), \mathrm{Chl} b\left(\mathrm{R}^{2}\right.$ $=0.816, \mathrm{n}=12)$ and $\mathrm{Chl}(\mathrm{a}+\mathrm{b})\left(\mathrm{R}^{2}=0.901, \mathrm{n}=12\right)($ Figure 7D), suggesting that salt-induced reduction in $\mathrm{P}_{\mathrm{N}}$ was also partially due to the decrease in chlorophyll content of M. sacchariflorus.
To understand the relationship between the decreases in dry matter and photosynthesis in Miscanthus, we determined the $\mathrm{P}_{\mathrm{N}}, \mathrm{F}_{\mathrm{v}} / \mathrm{F}_{\mathrm{m}}$ and ETR under salt stress as well as dry matter of plants and did the regression analysis under different salt concentrations. As shown in Figure 2, extremely significantly linearly positive correlation was found between total dry weight and $\mathrm{P}_{\mathrm{N}}, \mathrm{F}_{\mathrm{v}} / \mathrm{F}_{\mathrm{m}}$ or ETR, respectively, suggesting that biomass of plants was closely relative to the determined photosynthetic parameters under salt stress. Therefore, it is very important for breeding high biomass productivity of plant to maintain high photosynthesis under the stresses. In addition, even in the early growth stage, the image of chlorophyll fluorescence imaging system could detect the change of whole plant under salt stress. It will open a door in sight of fast response of plant to stresses.

Many studies have reported that salt stress increases the production of ROS $[23,35]$, which in turn activates a complex antioxidant defense system including non-enzymatic and enzymatic antioxidants. Recently, some studies have found that an increase in tolerance to salt stress is a positive correlation with the antioxidant capacity [3639]. In the current study, the activities of SOD and POD in the stressed shoot were much higher than that in the control, and the new shoot formation was extremely significantly $\left(R^{2}>0.99\right)$ or significantly $\left(R^{2}>0.93\right)$ correlated with the antioxidant enzymes activity (Figure 6). The results indicated that the new shoot had a higher capacity to scavenge ROS and was more tolerance than root and leaf under $\mathrm{NaCl}$ stress. Abiotic stresses cause oxidative stress through the increase of ROS, which lead to lipids peroxidation [37]. As a result, MDA is a product of lipid peroxidation and has been considered as an indicator of oxidative damage [2]. MDA content in shoot was always lower than that in leaf and root (Figure 5B), and the activities of SOD and POD in shoot were always higher than that in leaf and root in all salt concentrations (Figure 5), indicating that the new shoot suffered the less damage from oxidative stress under salt stress. Besides, proline is often referred as index for plant response to some stresses. Moradi [25] and Köşkeroğlu [19] also find that the increase in proline content may not be associated with salinity tolerance. However, salt tolerance species have higher accumulation of free proline compared with salt sensitive species [37]. Our results showed that the proline content increased markedly in all parts of M. sacchariflorus under salt stress (Figure 4). Therefore, higher SOD and POD activities which can protect it from lipid peroxidation may be an important mechanism for new shoots to resist higher salt stress and be play a potential for improving plant regeneration under salt stress.

\section{Conclusions}

To investigate the responses of the M. sacchariflorus to 
Citation: Hong C, Zheng B, Guo H, et al. (2018) Salt Stress Induces Shoot Formation and Physiological and Biochemical Changes in Miscanthus sacchariflorus. J Plant Biotechnol Res 1(1):16-25

salt stress, the seedlings of $M$. sacchariflorus were grown in hydroponics for $14 \mathrm{~d}$ with the different concentrations of $\mathrm{NaCl}(0,50,100$ and $200 \mathrm{mM})$. The results showed that many physiological and biochemical characteristics, including growth parameters, chlorophyll and proline content, gas exchange and antioxidant enzymes activities were changed. Dry biomass of all M. sacchariflorus organs was affected by $\mathrm{NaCl}$ treatments. No visible symptoms of salt toxicity were observed in shoots and leaves of plants grown in hydroponics supplemented with 50 and $100 \mathrm{mM} \mathrm{NaCl}$. Interestingly, all salt stress induced the novel shoot regeneration, and the proline and MDA content were lower in new shoots than those in leaves and roots. These results showed the new shoots could tolerate much higher salt stress than the leaves and roots, suggesting that new shoots could be used as a potential mechanism for improving plant growth under salt stress.

\section{Acknowledgments}

This work was supported by the Science and Technology Prosperity Project of Ningbo City (2016C10052).

\section{Conflict of Interest}

The authors declare that they have no conflict of interest.

\section{References}

1. Zhu JK (2002) Salt and drought stress signal transduction in plants. Annu Rev Plant Biol 53: 247-273.

2. Tang D, Shi S, Li D, et al. (2007) Physiological and biochemical responses of Scytonema javanicum (cyanobacterium) to salt stress. J Arid Environ 71: 312-320.

3. Chaves MM, Flexas J, Pinheiro C (2009) Photosynthesis under drought and salt stress: Regulation mechanisms from whole plant to cell. Ann Bot 103: 551-560.

4. Meloni DA, Oliva MA, Martinez CA, et al. (2003) Photosynthesis and activity of superoxide dismutase, peroxidase and glutathione reductase in cotton under salt stress. Environ Exp Bot 49: 69-76.

5. Zeng J, Chen A, Li D, et al. (2013) Effects of salt stress on the growth, physiological responses, and glycoside contents of Stevia rebaudiana Bertoni. J Agric Food Chem 61: 5720-5726.

6. Koca H, Bor M, Özdemir F, et al. (2007) The effect of salt stress on lipid peroxidation, antioxidative enzymes and proline content of sesame cultivars. Environ Exp Bot 60: 344-351.

7. de Azevedo Neto AD, Prisco JT, Enéas-Filho J, et al. (2006) Effect of salt stress on antioxidative enzymes and lipid peroxidation in leaves and roots of salt-tolerant and salt-sensitive maize genotypes. Environ Exp Bot 56: 87-94.

8. Sandalio LM, Dalurzo HC, Gomez M, et al. (2001) Cadmium-induced changes in the growth and oxidative metabolism of pea plants. J Exp Bot 52: 2115-2126.

9. Gill SS, Khan NA, Tuteja N (2012) Cadmium at high dose perturbs growth, photosynthesis and nitrogen metabolism while at low dose it up regulates sulfur assimilation and an- tioxidant machinery in garden cress (Lepidium sativum L.). Plant Sci 182: 112-120.

10. Benavídes MP, Marconi PL, Gallego SM, et al. (2000) Relationship between antioxidant defence systems and salt tolerance in Solanum tuberosum. Funct Plant Biol 27: 273-278.

11. Mandhania S, Madan S, Sawhney V (2006) Antioxidant defense mechanism under salt stress in wheat seedlings. Biol Plantarum 50: 227-231.

12. Scebba F, Arduini I, Ercoli L, et al. (2006) Cadmium effects on growth and antioxidant enzymes activities in Miscanthus sinensis. Biol Plantarum 50: 688-692.

13. Sharmin SA, Alam I, Kim KH, et al. (2012) Chromium-induced physiological and proteomic alterations in roots of Miscanthus sinensis. Plant Sci 187: 113-126.

14. Wang D, Portis AR, Moose SP, et al. (2008) Cool C4 photosynthesis: Pyruvate Pi dikinase expression and activity corresponds to the exceptional cold tolerance of carbon assimilation in Miscanthus $\times$ giganteus. Plant Physiol 148: 557-567.

15. Clifton-Brown JC, Lewandowski I (2000) Water use efficiency and biomass partitioning of three different Miscanthus genotypes with limited and unlimited water supply. Ann Bot 86: 191-200.

16. Ings J, Mur LA, Robson PR, et al. (2013) Physiological and growth responses to water deficit in the bioenergy crop Miscanthus $\times$ giganteus. Front Plant Sci 4: 468-479.

17. Von Caemmerer S, Farquhar GD (1981) Some relationships between the biochemistry of photosynthesis and the gas exchange of leaves. Planta 153: 376-387.

18. Hong CT, Guo HP, Fang J, et al. (2014) Physiological and biochemical responses of Miscanthus sacchariflorus to salt stress. Adv Mater Res 1051: 333-340.

19. Köşkeroğlu S, Tuna AL (2010) The investigation on accumulation levels of proline and stress parameters of the maize (Zea mays L.) plants under salt and water stress. Acta Physiol Plant 32: 541-549.

20. Rao KVM, Sresty TV (2000) Antioxidative parameters in the seedlings of pigeonpea (Cajanus cajan (L.) Millspaugh) in response to $\mathrm{Zn}$ and Ni stresses. Plant Sci 157: 113-128.

21. Cakmak I, Marschner H (1992) Magnesium deficiency and high light intensity enhance activities of superoxide dismutase, ascorbate peroxidase, and glutathione reductase in bean leaves. Plant Physiol 98: 1222-1227.

22. Medina-Pérez V, López-Laredo AR, Sepúlveda-Jiménez G, et al. (2015) Nitrogen deficiency stimulates biosynthesis of bioactive phenylethanoid glycosides in the medicinal plant Castilleja tenuiflora Benth. Acta Physiologia Plantarum 37: 1-8.

23. Jiang C, Belfield EJ, Mithani A, et al. (2012) ROS-mediated vascular homeostatic control of root-to-shoot soil Na delivery in Arabidopsis. EMBO J 31: 4359-4370.

24. da Silva EC, Nogueira RJMC, de Araújo FP, et al. (2008) Physiological responses to salt stress in young umbu plants. Environ Exp Bot 63: 147-157.

25. Moradi F, Ismail AM (2007) Responses of photosynthesis, chlorophyll fluorescence and ROS -scavenging systems to salt stress during seedling and reproductive stages in rice. Ann Bot 99: 1161-1173.

26. Sheng M, Tang M, Chen $\mathrm{H}$, et al. (2008) Influence of arbuscular mycorrhizae on photosynthesis and water status of maize plants under salt stress. Mycorrhiza 18: 287-296. 
Citation: Hong C, Zheng B, Guo H, et al. (2018) Salt Stress Induces Shoot Formation and Physiological and Biochemical Changes in Miscanthus sacchariflorus. J Plant Biotechnol Res 1(1):16-25

27. Nazar R, Iqbal N, Syeed S, et al. (2011) Salicylic acid alleviates decreases in photosynthesis under salt stress by enhancing nitrogen and sulfur assimilation and antioxidant metabolism differentially in two mungbean cultivars. J Plant Physiol 168: 807-815.

28. Zahra J, Nazim H, Cai S, et al. (2014) The influence of salinity on cell ultrastructures and photosynthetic apparatus of barley genotypes differing in salt stress tolerance. Acta Physiol Plant 36: 1261-1269.

29. He Y, Yu CL, Zhou L, et al. (2014) Rubisco decrease is involved in chloroplast protrusion and Rubisco-containing body formation in soybean (Glycine max.) under salt stress. Plant Physiol Biochem 74: 118-124.

30. Lu KX, Cao BH, Feng XP, et al. (2009) Photosynthetic response of salt-tolerant and sensitive soybean varieties. Photosynthetica 47: 381-387.

31. Farquhar GD, Sharkey TD (1982) Stomatal conductance and photosynthesis. Annu Rev Plant Physiol 33: 317-345.

32. Yang Y, Yan CQ, Cao BH, et al. (2007) Some photosynthetic responses to salinity resistance are transferred into the somatic hybrid descendants from the wild soybean Glycine cyrtoloba ACC547. Plant Physiol 129: 658-669.

33. Demmig-Adams B, Adams lii WW (1992) Photoprotection and other responses of plants to high light stress. Annu Rev Plant Physiol Plant Mol Biol 43: 599-626.
34. Asada K (1999) The water-water cycle in chloroplasts: Scavenging of active oxygens and dissipation of excess photons. Annu Rev Plant Physiol Plant Mol Biol 50: 601-639.

35. Miller G, Suzuki N, Ciftci-Yilmaz S, et al. (2010) Reactive oxygen species homeostasis and signaling during drought and salinity stresses. Plant Cell Environ 33: 453-467.

36. Mittova V, Tal M, Volokita M, et al. (2003) Up-regulation of the leaf mitochondrial and peroxisomal antioxidative systems in response to salt-induced oxidative stress in the wild salt-tolerant tomato species Lycopersicon pennellii. Plant Cell Environ 26: 845-856.

37. Sekmen AH, Turkan I, Tanyolac ZO, et al. (2012) Different antioxidant defense responses to salt stress during germination and vegetative stages of endemic halophyte Gypsophila oblanceolata Bark. Environ Exp Bot 77: 63-76.

38. Rasool S, Ahmad A, Siddiqi TO, et al. (2013) Changes in growth, lipid peroxidation and some key antioxidant enzymes in chickpea genotypes under salt stress. Acta Physiol Plant 35: 1039-1050.

39. Diaz-Vivancos P, Faize M, Barba-Espin G, et al. (2013) Ectopic expression of cytosolic superoxide dismutase and ascorbate peroxidase leads to salt stress tolerance in transgenic plums. Plant Biotechnol J 11: 976-985. 